\title{
A COMPARATIVE STUDY OF CLINICO- PATHOLOGICAL AND RADIOLOGICAL FEATURES OF PALPABLE BREAST LESIONS
}

\author{
Vinu Sugathan', Sheela Varghese ${ }^{2}$, Laila Raji $N^{3}$ \\ ${ }^{1}$ Senior Resident, Department of Pathology, Government Medical College, Kottayam, Kerala. \\ ${ }^{2}$ Assistant Professor, Department of Pathology, Government Medical College, Kottayam, Kerala. \\ ${ }^{3}$ Professor, Department of Pathology, Government Medical College, Kottayam, Kerala.
}

\section{ABSTRACT}

\section{BACKGROUND}

Breast cancer is the most common cancer in Indian cities and the second most common cancer in the rural areas. More and more patients are being diagnosed with breast cancer in their thirties and forties. Early diagnosis is therefore very important for reduction of morbidity and mortality associated with breast cancer.

\section{MATERIALS AND METHODS}

Currently the triple test (Clinical examination, radiological imaging and FNAC) is used to accurately diagnose all palpable breast lumps. This study was undertaken to assess the sensitivity and specificity of mammography and fine needle aspiration cytology. A total of 172 cases which had a combination of clinical examination, fine needle aspiration cytology, mammography and histopathological examination were analysed.

\section{RESULTS}

Benign tumours were common in young women, with incidence peaking at 20-29 years of age. Majority of the malignant breast lesions were seen in the age group of 50-59 years. The mean age of breast cancer was 53.89 years. Breast lump was the most common presenting complaint in both benign and malignant breast lesions. Upper outer quadrant was the most common site of breast lump in both benign and malignant breast lesions. The most common benign lesion was fibroadenoma (58.5\%). The most common malignant lesion was invasive carcinoma of no special type $(82.3 \%)$. The sensitivity and specificity of FNAC were $97.02 \%$ and $98.57 \%$ respectively. The sensitivity and specificity of mammography were $92.15 \%$ and $87.14 \%$ respectively.

\section{CONCLUSION}

Fine needle aspiration cytology is more sensitive and specific in the diagnosis of palpable breast lesions. Hence fine needle aspiration cytology alone may be sufficient for the accurate diagnosis of palpable breast lesions.

\section{KEYWORDS}

Triple Test, Carcinoma Breast, FNAC, Mammography.

HOW TO CITE THIS ARTICLE: Sugathan V, Varghese S, Raji LN. A comparative study of clinico- pathological and radiological features of palpable breast lesions. J. Evolution Med. Dent. Sci. 2017;6(10):770-776, DOI: 10.14260/Jemds/2017/167

\section{BACKGROUND}

The rising incidence of carcinoma breast is a major concern worldwide and it is the most common cancer, and the most common cause of cancer deaths in Indian women. ${ }^{1}$ Accurate diagnosis is essential for relieving the anxiety of the patient and for appropriate treatment at the earliest. The most common symptom of breast cancer is a lump. Although clinical examination can suggest a carcinoma breast, there is variable degree of suspicion. ${ }^{2}$ The triple test which uses a combination of clinical examination, radiological imaging (mammogram/ultrasound) and Fine needle aspiration cytology remains the gold standard for accurate diagnosis of carcinoma breast.2,3,4 The "Triple test," was initially described in the mid-1970s, by Johansen C.

The Triple test has proved a reliable tool for the accurate diagnosis of palpable breast masses, due to its technical

Financial or Other, Competing Interest: None.

Submission 08-12-2016, Peer Review 19-01-2017,

Acceptance 25-01-2017, Published 02-02-2017.

Corresponding Author:

Dr. Sheela Varghese,

Assistant Professor,

Department of Pathology,

Government Medical College,

Kottayam, Kerala.

E-mail: drsheelavarghese@gmail.com

DOI: $10.14260 /$ jemds/2017/167 simplicity, and resulted in substantially reduced expense and morbidity compared with open surgical biopsy.5,6,7 This study titled "A comparative study of clinico pathological and radiological features of palpable breast lesions" was undertaken for assessment of BIRADS grading of mammography versus fine needle aspiration cytology and determining the sensitivity and specificity of mammography and fine needle aspiration cytology.

\section{MATERIALS AND METHODS}

Study Design- Prospective comparative study.

Study Setting- Dept. of Pathology, Government Medical College, Kottayam.

Study Period- June 2014 to September 2015 (16 months).

\section{Study Subjects}

Cases of palpable breast lesions who came to the department of pathology for FNAC study, satisfying the inclusion and exclusion criteria;

\section{Inclusion Criteria}

1. All female patients who presented with palpable breast lesions to the department of pathology for fine needle aspiration study.

2. Cases in which all the three components of triple test were studied. 


\section{Exclusion Criteria}

1. Patients presenting with breast complaints other than palpable breast lesions and patients in whom no definable mass can be detected on physical examination. Ulcerated and fungating breast growth are excluded.

2. Patients who did not have a combination of physical examination, mammography FNAC and histopathology.

\section{Sample Size}

Sample size $=\frac{\mathrm{z}^{2} * \text { Specificity (1-Specificity) }}{\mathrm{W}^{2}(1-\mathrm{P})}$

A recent study had shown that mammography had $90.3 \%$ specificity and FNAC had $97.2 \%$ specificity in diagnosing malignant disease. Assuming a prevalence of the malignant disease in the study population as $20 \%$ of all the breast lumps $\mathrm{Z}=1.96$ for $95 \%$ confidence

Specificity of Mammography as $90.3 \%$ from a previous study $\mathrm{W}=0.05$

\section{Sample Size $=172$}

As the sample size calculated using specificity of FNAC is less than that of mammography, the sample size 172 has been chosen.

(Rahman MZ, Sikder AM, Nabi SR. Diagnosis of breast lump by fine needle aspiration cytology and mammography. Mymensingh Med J. 2011 Oct; 20(4):658-64).

\section{Statistics}

The Data were appropriately coded and entered in Microsoft Office Excel. Appropriate statistical tests were used and further analysis was done using Statistical Package for Social Sciences (SPSS) software (Version 16).

\section{Fine Needle Aspiration Cytology Results were classified} as

1. Non-diagnostic (Inadequate or unsatisfactory).

2. Negative for malignant cells (No malignant cells seen).

3. Atypical.

4. Suspicious.

5. Positive for malignant cells.

Category 1 was excluded from the study.

Category 2 and 3 were taken as negative for the diagnosis of malignancy.

Category 4 and 5 was taken as positive for the diagnosis of malignancy.

\section{Mammography Results were classified as}

0 - Incomplete.

1- Negative.

2- Benign.

3- Probably benign.

4- Suspicious.

5- Highly suggestive of malignancy.

6- Biopsy proven malignancy.

Categories 1, 2 and 3 were taken as negative for malignancy.

Categories 4, 5 and 6 were taken as positive for malignancy.
The Values were determined by the following Formula

Where TP is true positive, TN-true negative, FP-False Positive and FN-False Negative.

Sensitivity $=\mathrm{TP} /(\mathrm{TP}+\mathrm{FN})$.

Specificity $=\mathrm{TN} /(\mathrm{TN}+\mathrm{FP})$.

\section{RESULTS}

\section{A Total of 172 Cases were included in the Study}

All patients were females. The age ranged from 15 to 88 years. There were a total of 102 malignant lesions and 70 benign lesions.

Benign breast diseases were common in younger age groups $(<30$ years) with peak incidence in the age group 20 29 years. (Table 1 ).

Malignant breast lesions were common in older age groups with peak incidence in $50-59$ years. (Table 1 ).

The mean age of breast cancer was 53.89 years.

Breast lump was the most common presenting complaint in both benign and malignant breast lesions.

Upper outer quadrant was the most common site of breast lump in both benign and malignant breast lesions. (Figure 1 and 2).

The most common benign lesion was fibroadenoma (58.5\%) followed by fibrocystic disease (20\%) (Table 2).

The most common malignant lesion was invasive carcinoma of no special type (82.3\%) followed invasive lobular carcinoma and mucinous carcinoma (3.9\% each) (Table 2).

The sensitivity and specificity of FNAC was higher (97.02\% and $98.57 \%$ respectively) compared to mammography $(92.15 \%$ and $87.14 \%$ respectively) in detecting breast malignancy (Table 3 and figure 3).

Mammography had a higher sensitivity (92.39\%) in detecting malignancy in older women ( $>40$ years of age) when compared to women below 40 years (Table 4 and table 5).

\begin{tabular}{|c|c|c|}
\hline $\begin{array}{c}\text { Age Group } \\
\text { (Years) }\end{array}$ & $\begin{array}{c}\text { Benign } \\
\text { Lesions }\end{array}$ & $\begin{array}{c}\text { Malignant } \\
\text { Lesions }\end{array}$ \\
\hline $0-19$ & 14 & 0 \\
\hline $20-29$ & 20 & 0 \\
\hline $30-39$ & 14 & 10 \\
\hline $40-49$ & 16 & 29 \\
\hline $50-59$ & 4 & 33 \\
\hline $60-69$ & 1 & 21 \\
\hline $70-79$ & 1 & 6 \\
\hline $80-89$ & 0 & 3 \\
\hline \multicolumn{2}{|c|}{ Table 1. Age wise distribution of } \\
benign and malignant breast lesions \\
\hline
\end{tabular}

\begin{tabular}{|c|c|c|c|}
\hline Benign & $\begin{array}{c}\text { No. of } \\
\text { Lesions }\end{array}$ & Malignant & $\begin{array}{c}\text { No. of } \\
\text { Lesions }\end{array}$ \\
\hline Fibroadenoma & 41 & $\begin{array}{c}\text { Ductal } \\
\text { Carcinoma In } \\
\text { Situ }\end{array}$ & 2 \\
\hline Fibrocystic Disease & 14 & $\begin{array}{c}\text { Invasive } \\
\text { Carcinoma of } \\
\text { No Special } \\
\text { Type }\end{array}$ & 84 \\
\hline $\begin{array}{c}\text { Fibroadenomatoid } \\
\text { Hyperplasia }\end{array}$ & 6 & $\begin{array}{c}\text { Invasive } \\
\text { Lobular } \\
\text { Carcinoma }\end{array}$ & 4 \\
\hline
\end{tabular}




\begin{tabular}{|c|c|c|c|}
\hline Tubular Adenoma & 1 & $\begin{array}{c}\text { Mucinous } \\
\text { Carcinoma }\end{array}$ & 4 \\
\hline $\begin{array}{c}\text { Benign Phyllodes } \\
\text { (Figure 3 a, b, c) }\end{array}$ & 4 & $\begin{array}{c}\text { Invasive } \\
\text { Papillary } \\
\text { Carcinoma }\end{array}$ & 3 \\
\hline Sclerosing Adenosis & 1 & $\begin{array}{c}\text { Solid Papillary } \\
\text { Carcinoma }\end{array}$ & 1 \\
\hline $\begin{array}{c}\text { Pseudoangiomatous } \\
\text { Stromal Hyperplasia }\end{array}$ & 1 & $\begin{array}{c}\text { Carcinoma } \\
\text { with } \\
\text { Medullary } \\
\text { Features }\end{array}$ & 1 \\
\hline Breast Abscess & 1 & $\begin{array}{c}\text { Metaplastic } \\
\text { Carcinoma }\end{array}$ & 1 \\
\hline \multicolumn{2}{|c|}{ Granulomatous } \\
Mastitis & 1 & $\begin{array}{c}\text { Malignant } \\
\text { Phyllodes } \\
\text { Tumor }\end{array}$ & 2 \\
\hline \multicolumn{2}{|c|}{ Table 2. Histological types of Lesions } \\
\hline
\end{tabular}

In this study FNAC was found to be more sensitive and specific (97.02\% and 98.57\%) as compared to mammography (92.15\% and $87.14 \%)$.

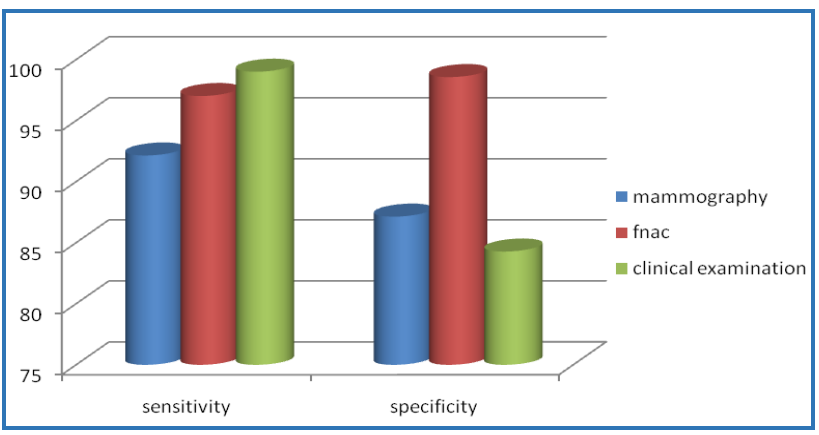

Figure 3. Comparison of sensitivity and specificity of mammography, FNAC and clinical examination

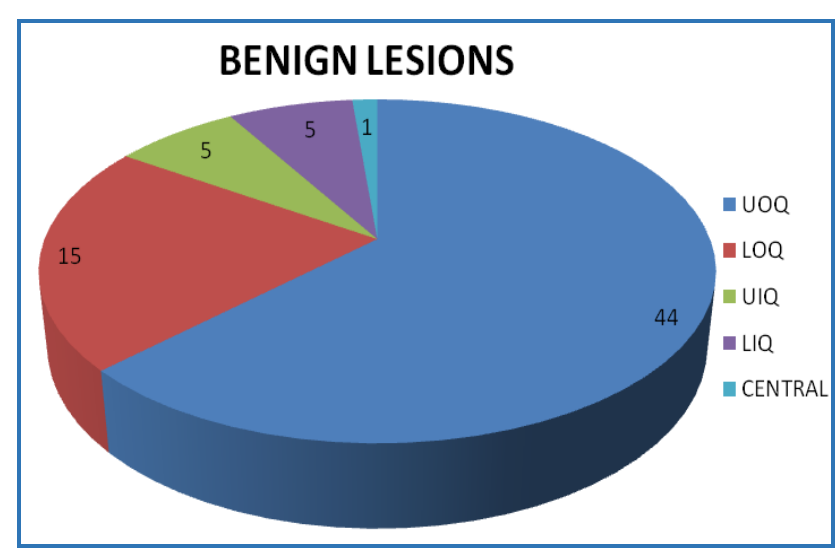

Figure 1. Quadrant wise distribution of benign breast lesions

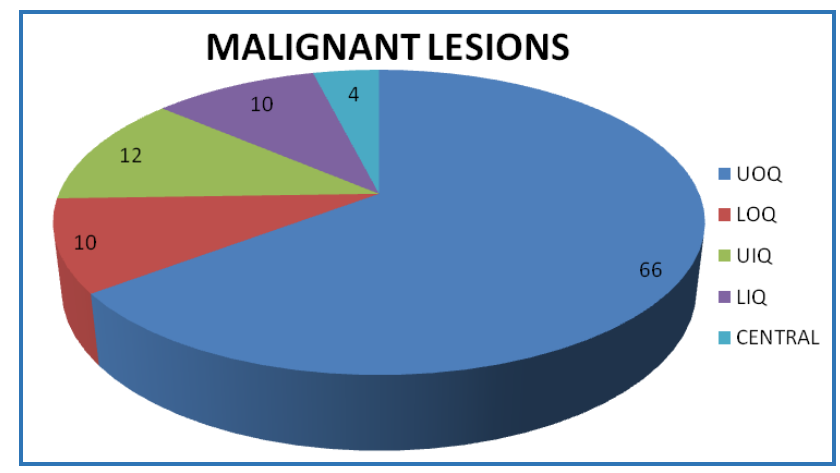

Figure 2. Quadrant wise distribution of malignant breast lesions

\begin{tabular}{|c|c|c|c|}
\hline Diagnosis & $\begin{array}{c}\text { Mammo- } \\
\text { graphy }\end{array}$ & FNAC & $\begin{array}{c}\text { Clinical } \\
\text { Examination }\end{array}$ \\
\hline $\begin{array}{c}\text { True } \\
\text { Positive (TP) }\end{array}$ & 94 & 98 & 101 \\
\hline $\begin{array}{c}\text { True } \\
\text { Negative (Tn) }\end{array}$ & 61 & 69 & 59 \\
\hline $\begin{array}{c}\text { False } \\
\text { Positive (FP) }\end{array}$ & 9 & 1 & 11 \\
\hline $\begin{array}{c}\text { False } \\
\text { Negative (FN) }\end{array}$ & 8 & 3 & 1 \\
\hline $\begin{array}{c}\text { Sensitivity } \\
\text { TP/(TP+FN) }\end{array}$ & $92.15 \%$ & $97.02 \%$ & $99.01 \%$ \\
\hline $\begin{array}{c}\text { Specificity } \\
\text { TN/(TN+FP) }\end{array}$ & $87.14 \%$ & $98.57 \%$ & $84.28 \%$ \\
\hline \multicolumn{4}{|c|}{ Table 3. Sensitivity \& specificity of } \\
mammography, FNAC and clinical examination \\
\hline
\end{tabular}

\begin{tabular}{|c|c|c|}
\hline & Mammogram & FNAC \\
\hline Sensitivity & $92.39 \%$ & $96.74 \%$ \\
\hline Specificity & $77.27 \%$ & $95.45 \%$ \\
\hline \multicolumn{3}{|c|}{$\begin{array}{c}\text { Table 4. Comparison of sensitivity and specificity } \\
\text { of mammography and FNAC in women } \\
\text { above } 40 \text { years of age }\end{array}$} \\
\hline & Mammogram & FNAC \\
\hline Sensitivity & $90.00 \%$ & $100 \%$ \\
\hline Specificity & $91.67 \%$ & $100 \%$ \\
\hline \multicolumn{3}{|c|}{$\begin{array}{c}\text { Table 5. Comparison of sensitivity and specificity } \\
\text { of mammography and FNAC in women } \\
\text { below } 40 \text { years of age }\end{array}$} \\
\hline
\end{tabular}

Mammogram had a greater sensitivity in detecting breast cancers in women above 40 years of age compared to women below 40 .

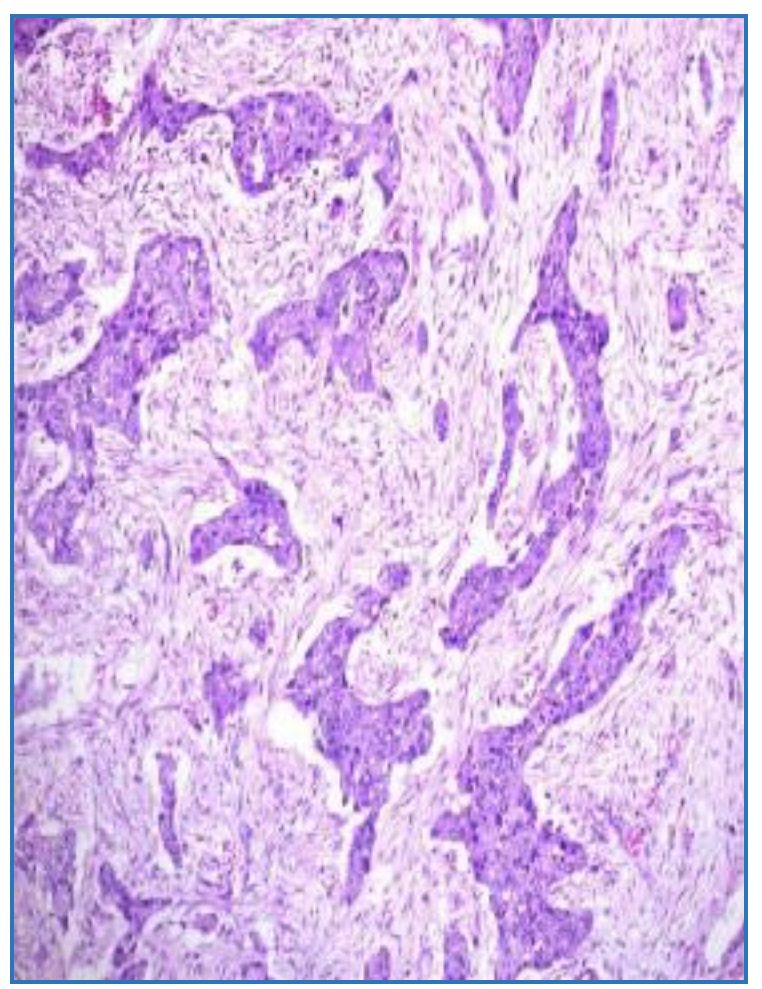

Figure 1a. Invasive carcinoma of no special type, $\mathrm{H} \& \mathrm{E}$ stain, $10 \mathrm{X}$ 




Figure 1b. Mammography BIRADS V. carcinoma breast

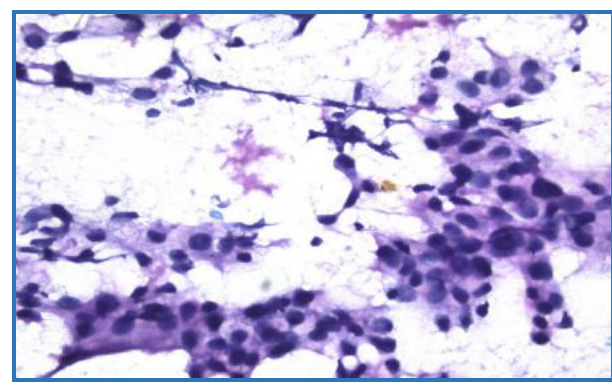

Figure 1c. Carcinoma breast, Papanicolaou stain, $20 \mathrm{X}$

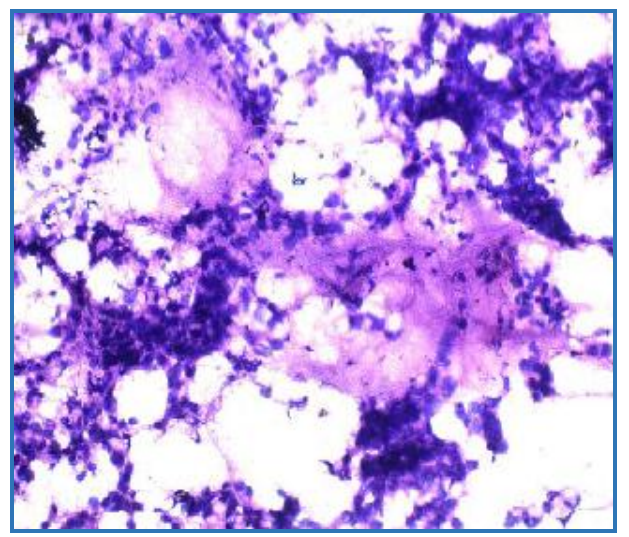

Figure 2a. Mucinous carcinoma, Papanicolaou stain; 20X

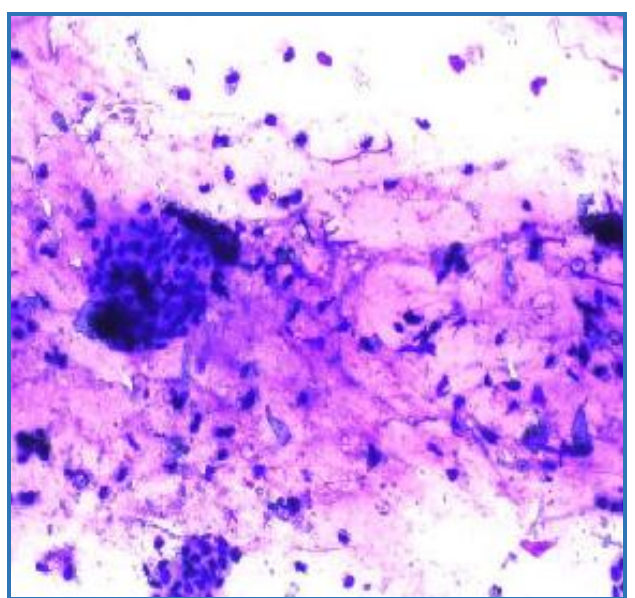

Figure 2b. Mucinous carcinoma, Giemsa stain; $20 \mathrm{X}$

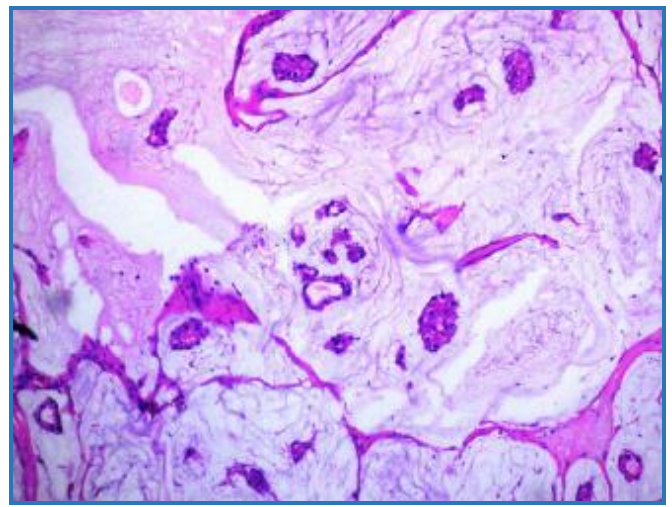

Figure 2c. Mucinous carcinoma, H \& E stain; $20 X$

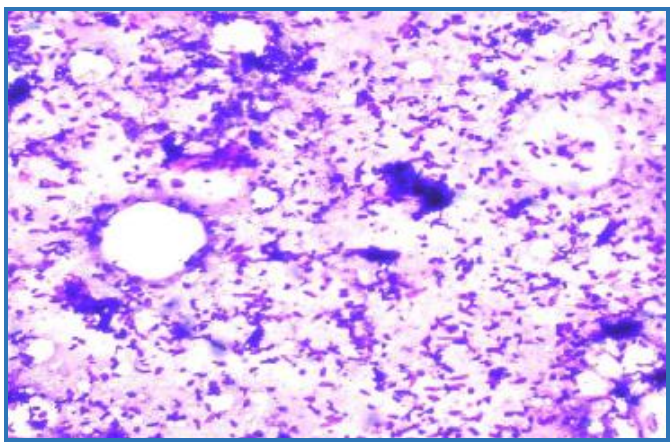

Figure 3a. Phyllodes tumor, Papanicolaou stain, $20 \mathrm{X}$

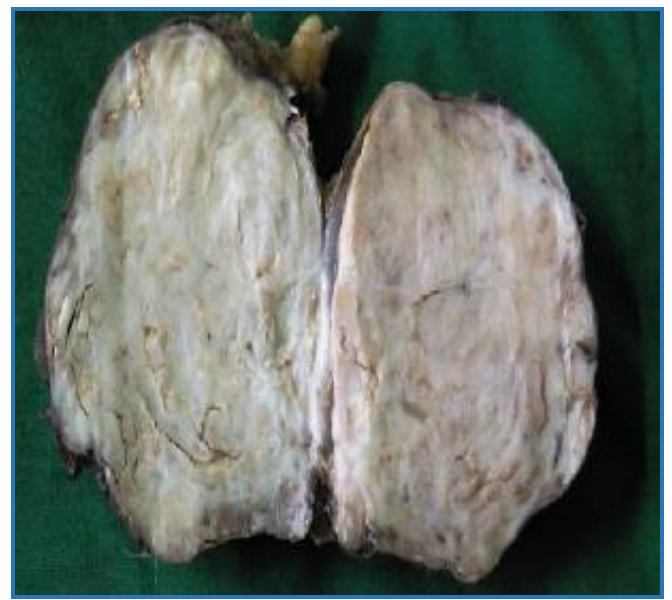

Figure 3b. Gross phyllodes tumor

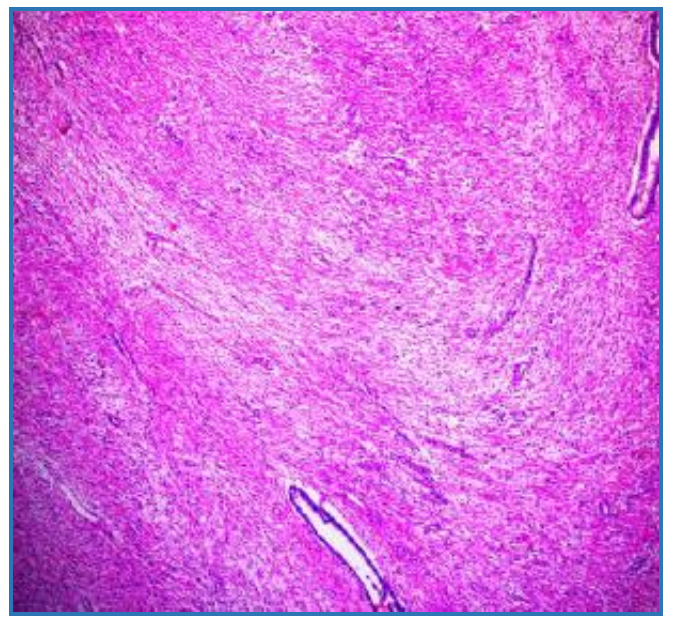

Figure 3c. Benign phyllodes tumor, H \& E stain; $20 X$ 


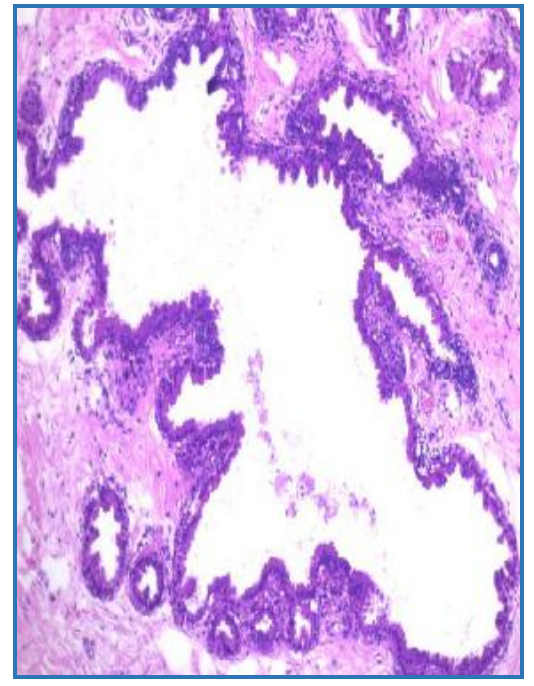

Figure 4a. Fibrocystic disease, $\mathrm{H} \& \mathrm{E}$ stain, $20 \mathrm{X}$

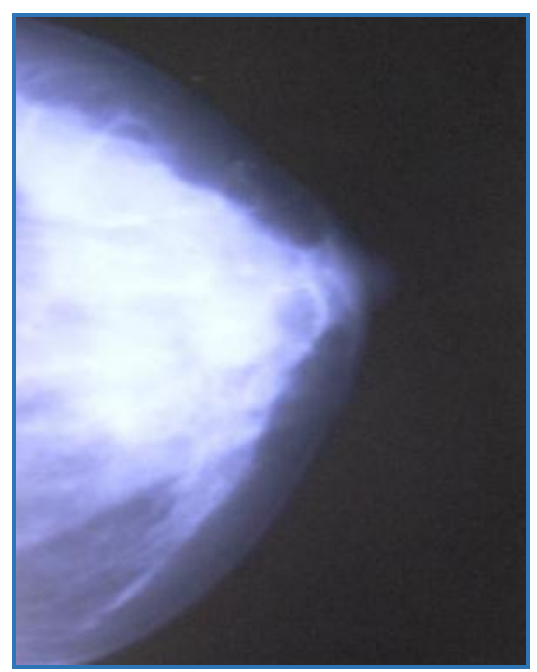

Figure 4b. Mammography cystic lesion breast

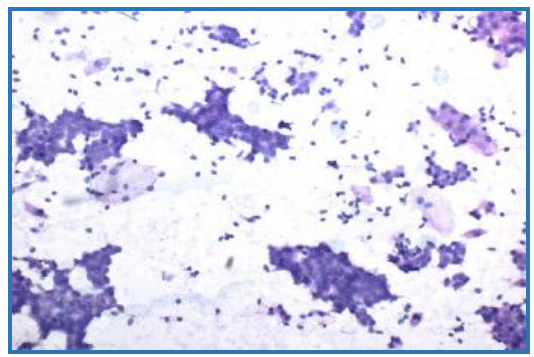

Figure 4c. Fibrocystic disease, Papanicolaou stain; $20 \mathrm{X}$

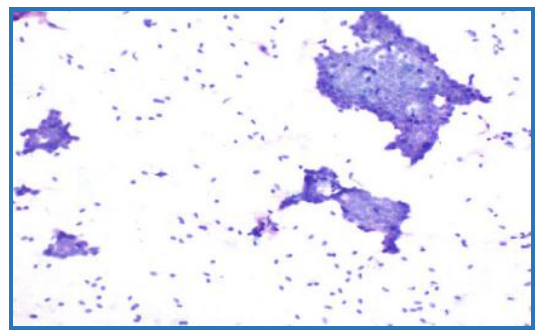

Figure 5a. Fibroadenoma; Papanicolaou stain, 20X

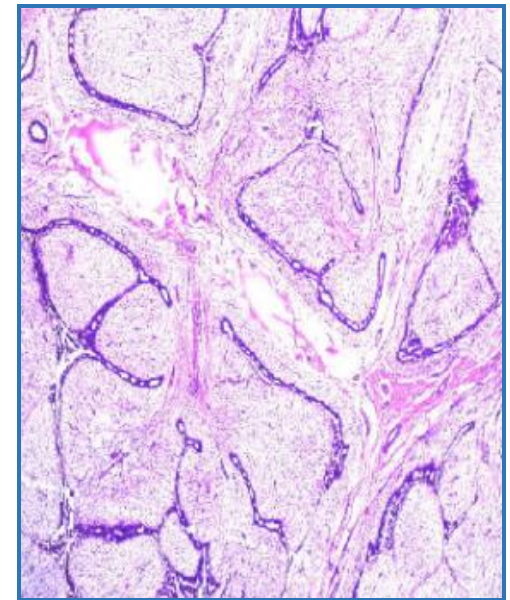

Figure 5b. Fibroadenoma H \& E stain; 10X;

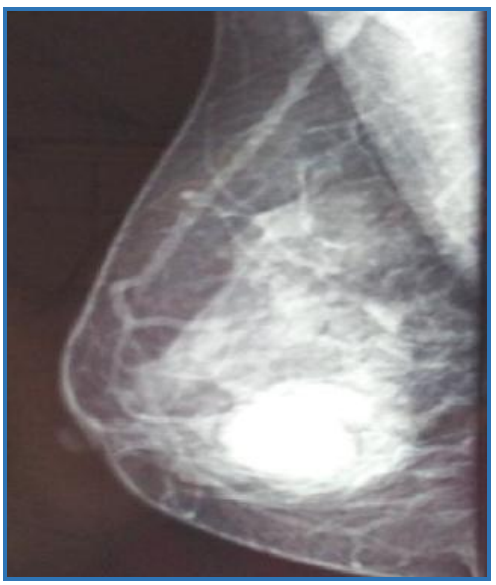

Figure 5c. Mammography, lobulated lesion, BIRADS II

\section{DISCUSSION}

\section{Age}

The youngest patient was 15 years and the oldest was 88 years. There were 70 benign lesions and 102 malignant lesions. The increase in the number of malignant lesions may be due to selection bias. Benign lesions were common in the younger age group, whereas malignant lesions were common in the older age groups. The mean age of breast cancer was 53.89 years. The highest number of malignant lesions were in the age group 40-59 years. The mean age of presentation was 47.8 years in the study done by Sunita Saxena et al ${ }^{8}$ In US white females, the average age of occurrence of breast cancer is 61 years. $^{9}$ The peak age of breast cancer onset is $45-$ 50 years of age in Asia and 55-60 years in the Western countries, according to Stanley P Leong et al10. The maximum number of cases of breast cancer were between 50 to 54 years of age group in TS Sanal et al study. The mean age of the cases was 45.64 years .11

The mean age of presentation was higher in the present study as compared to the Indian studies and was lower compared to western study. The disease occurs a decade earlier in India as compared to the west. The reasons need to be evaluated further. All lesions in the age group 0-29 were benign lesions. The highest number of benign lesions were seen in the age group 20-29 years. 


\section{Symptoms}

The most common presenting complaint was a painless lump, followed by lump with pain. Babatunde A Ayoade et al study 12 also showed that breast lump was the most common symptom of patients in benign and malignant breast diseases. Jagdish B. Karia et al study ${ }^{13}$ and MBM Sangma et al ${ }^{14}$ studies showed similar results.

\section{Quadrant}

Both benign and malignant breast lumps were in the upper outer quadrant. Vishal GM et al ${ }^{15}$ and Mohapatra et al ${ }^{16}$ studies also give similar results. Darbre P D et al ${ }^{17}$ study found that incidence of female breast cancer in the UOQ rose from $47.9 \%$ in 1979 to $53.3 \%$ in 2000 .

\section{Histological Type of Breast Lesions}

Invasive carcinoma of no special type was the most common followed by invasive lobular carcinoma and mucinous carcinoma. Sunita Saxena et al study ${ }^{8}$ and Sangeetha K et al study ${ }^{18}$ also showed similar results. (Table 6).

The most common benign lesion was fibroadenoma followed by fibrocystic disease. Sangeetha K et al study ${ }^{18}$ and AN Olu Eddo et al ${ }^{19}$ study showed similar results. (Table 7).

\section{Sensitivity and specificity of FNAC}

The reported sensitivity and specificity of FNAC vary depending on how insufficient/non-diagnostic samples and atypical/indeterminate samples are considered (Positive, negative or excluded from the study). In this study, insufficient/non-diagnostic samples were excluded and atypical/indeterminate samples were considered as benign.

The sensitivity and specificity of FNAC were $97.02 \%$ and 98.57\% respectively. The results of the present study were comparable to Rahman MZ et al20 study and showed higher sensitivity and specificity compared to Ying-Hua $\mathrm{Yu}$ et al ${ }^{21}$ study and Puja B. Jarwani Et al study22 (Table 8).

\section{Sensitivity and Specificity of Mammography}

In the present study sensitivity and specificity of mammography were $92.15 \%$ and $87.14 \%$ respectively.

The Gurung et al 23 and Rahman MZ et al study ${ }^{24}$ showed higher specificities compared to sensitivity. Ahmadinejad et al study 25 showed a high sensitivity but had very low specificity compared to the present study. (Table 9).

\section{Sensitivity of Mammography and Age of the Patient}

In the present study, mammogram had higher sensitivity in patients above forty years of age (92.39\%) compared to those younger than forty. (90.00\%). similar observations were made by Saarenmaa et $\mathrm{al}^{26}$ and Houssami et $\mathrm{al}^{24}$ in their studies.

\begin{tabular}{|c|c|c|c|}
\hline Histological Type & $\begin{array}{c}\text { Present } \\
\text { Study }\end{array}$ & $\begin{array}{c}\text { Sunita } \\
\text { Saxena } \\
\text { et al Study }\end{array}$ & $\begin{array}{c}\text { Sangeeta k } \\
\text { et al Study } \mathbf{1 8}\end{array}$ \\
\hline $\begin{array}{c}\text { Ductal Carcinoma In } \\
\text { Situ }\end{array}$ & $1.9 \%$ & $1.1 \%$ & \\
\hline $\begin{array}{c}\text { Invasive Carcinoma of } \\
\text { No Special Type }\end{array}$ & $82.3 \%$ & $88.2 \%$ & $84.85 \%$ \\
\hline $\begin{array}{c}\text { Invasive Lobular } \\
\text { Carcinoma }\end{array}$ & $3.9 \%$ & $3.7 \%$ & $3.03 \%$ \\
\hline Mucinous Carcinoma & $3.9 \%$ & - & $3.03 \%$ \\
\hline
\end{tabular}

\begin{tabular}{|c|c|c|c|}
\hline $\begin{array}{c}\text { Invasive Papillary } \\
\text { Carcinoma }\end{array}$ & $2.9 \%$ & - & - \\
\hline $\begin{array}{c}\text { Solid Papillary } \\
\text { Carcinoma }\end{array}$ & $0.98 \%$ & - & - \\
\hline $\begin{array}{c}\text { Carcinoma with } \\
\text { Medullary Features }\end{array}$ & $0.98 \%$ & $1.1 \%$ & - \\
\hline $\begin{array}{c}\text { Metaplastic } \\
\text { Carcinoma }\end{array}$ & $0.98 \%$ & $0.9 \%$ & - \\
\hline $\begin{array}{c}\text { Malignant Phyllodes } \\
\text { Tumor }\end{array}$ & $1.9 \%$ & - & - \\
\hline \multicolumn{4}{|c|}{ Table 6. Comparison of histological types of } \\
malignant breast lesions with similar studies \\
\hline
\end{tabular}

\begin{tabular}{|c|c|c|c|}
\hline $\begin{array}{c}\text { Histological } \\
\text { Type }\end{array}$ & $\begin{array}{c}\text { Present } \\
\text { Study }\end{array}$ & $\begin{array}{c}\text { Sangeetha k } \\
\text { et al Study }{ }^{18}\end{array}$ & $\begin{array}{c}\text { AN Olu Eddo } \\
\text { et al study }\end{array}$ \\
\hline Fibroadenoma & $58.5 \%$ & $62.32 \%$ & $43.1 \%$ \\
\hline Fibrocystic Disease & $20 \%$ & $11.59 \%$ & $23.8 \%$ \\
\hline $\begin{array}{c}\text { Fibroadenomatoid } \\
\text { Hyperplasia }\end{array}$ & $8.6 \%$ & & \\
\hline Tubular Adenoma & $1.4 \%$ & & $1.8 \%$ \\
\hline Benign Phyllodes & $5.7 \%$ & $1.45 \%$ & \\
\hline Sclerosing Adenosis & $1.4 \%$ & $4.35 \%$ & \\
\hline $\begin{array}{c}\text { Pseudoangiomatous } \\
\text { Stromal Hyperplasia }\end{array}$ & $1.4 \%$ & & $1.5 \%$ \\
\hline Breast Abscess & $1.4 \%$ & $1.45 \%$ & \\
\hline $\begin{array}{c}\text { Granulomatous } \\
\text { Mastitis }\end{array}$ & $1.4 \%$ & & \\
\hline \multicolumn{4}{|c|}{$\begin{array}{c}\text { Table 7. Comparison of histological types of } \\
\text { benign breast lesions with similar studies }\end{array}$} \\
\hline
\end{tabular}

\begin{tabular}{|c|c|c|c|c|}
\hline FNAC & $\begin{array}{c}\text { Present } \\
\text { Study }\end{array}$ & $\begin{array}{c}\text { Rahman } \\
\text { MZ } \\
\text { et al } \\
\text { Study 20 }\end{array}$ & $\begin{array}{c}\text { Ying-Hua } \\
\text { Yu } \\
\text { et al } \\
\text { Study }\end{array}$ & $\begin{array}{c}\text { Puja B. } \\
\text { Jarwani } \\
\text { et al } \\
\text { Study }\end{array}$ \\
\hline Sensitivity & $97.02 \%$ & $97.22 \%$ & $92.7 \%$ & $87.1 \%$ \\
\hline Specificity & $98.57 \%$ & $99.46 \%$ & $92.1 \%$ & $87.5 \%$ \\
\hline \multicolumn{3}{|c|}{ Table 8. Comparison of sensitivity \& specificity of } \\
FNAC of the present study with similar studies \\
\hline
\end{tabular}

\begin{tabular}{|c|c|c|c|c|}
\hline Mammography & $\begin{array}{c}\text { Present } \\
\text { Study }\end{array}$ & $\begin{array}{c}\text { Rahman } \\
\text { MZ } \\
\text { et al } \\
\text { Study }\end{array}$ & $\begin{array}{c}\text { Ahmadinejad } \\
\text { et al } \\
\text { Study }^{25}\end{array}$ & $\begin{array}{c}\text { Gurung } \\
\text { et al } \\
\text { Study }\end{array}$ \\
\hline Sensitivity & $92.15 \%$ & $82.76 \%$ & $94.1 \%$ & $88.9 \%$ \\
\hline Specificity & $87.14 \%$ & $90.36 \%$ & $55.6 \%$ & $95.53 \%$ \\
\hline
\end{tabular}

Table 9. Comparison of sensitivity \& specificity of mammography of the present study with similar studies

\section{CONCLUSION}

Timely detection plays a pivotal role in the management and prognosis of patients with carcinoma breast. The triple test continues to be the most reliable tool for the diagnosis of carcinoma breast. Even though in this study all the three components of the triple test are highly sensitive, fine needle aspiration cytology shows higher specificity than mammography and clinical examination. Compared to mammography, FNAC is more sensitive and specific in palpable breast lesions. Hence fine needle aspiration cytology alone may be sufficient for the accurate diagnosis of palpable breast lesions. In case of nonpalpable breast lesions, mammography continues to play a major role in the diagnosis. 


\section{REFERENCES}

[1] Ferlay J, Soerjomataram I, Dikshit R, et al. Cancer incidence and mortality worldwide: sources, methods and major patterns in GLOBOCAN 2012. Int J Cancer 2015;136(5):E359-86.

[2] Barton MB, Harris R, Fletcher SW. The rational clinical examination. Does this patient have breast cancer? The screening clinical examination: should it be done? How? JAMA 1999;282(3):1270-80.

[3] Kharkwal S, Sameer, Mukherjee A. Triple test in carcinoma breast. J Clin Diagn Res 2014;8(10): NC09-11.

[4] Ghimire B, Khan MI, Bibhusal T, et al. Accuracy of triple test score in the diagnosis of palpable breast lump. JNMA J Nepal Med Assoc 2008;47(172):189-92.

[5] Graf 0, Herbich TH. Follow up of palpable circumscribed non-calcified solid breast masses at mammography and ultrasound: can biopsy be averted? Radiology 2004;233(3):850-6.

[6] Westenend PJ, Sever AR, Beekman-De Volder HJ, et al. A comparison of aspiration cytology and core needle biopsy in the evaluation of breast lesions. Cancer 2001;93(2):146-50.

[7] Morris A, Pommier RF, Schmidt WA, et al. Accurate evaluation of palpable breast masses by the triple test score. Arch Surg 1998;133(9):930-4.

[8] Saxena S, Rekhi B, Bansal A, et al. Clinicomorphological patterns of breast cancer including family history in a New Delhi hospital, India-a crosssectional study. World J Surg Oncol 2005;3:67.

[9] Anderson WF, Pfeiffer RM, Dores GM, et al. Comparison of age distribution patterns for different histopathologic types of breast carcinoma. Cancer Epidemiol Biomarkers Prev 2006;15(10):1899-905.

[10] Leong SP, Shen ZZ, Liu TJ, et al. Is breast cancer the same disease in Asian and western countries? World J Surg 2010;34(10):2308-24.

[11] Kamath R, Mahajan KS, Ashok L, et al. A study on risk factors of breast cancer among patients attending the tertiary care hospital, in udupi district. Indian J Community Med 2013;38(2):95-9.

[12] Ayoade BA, Tade AO, Salami BA. Clinical features and pattern of presentation of breast diseases in surgical outpatient clinic of a suburban tertiary hospital in south-west Nigeria. Niger J Surg 2012;18(1):13-6.

[13] Karia JB, Kothari MD, Palekar HD, et al. Clinical features and pattern of presentation of breast diseases in surgical outpatient clinic of a tertiary hospital. National Journal of Medical Research 2014;4(1):40-2.
[14] Sangma MBM, Panda K, Dasiah S. A clinicopathological study on benign breast diseases. J Clin Diagn Res 2013;7(3):503-6.

[15] Mudholkar VG, Kawade SB, Mashal SN. Histopathological study of neoplastic lesions of breast. Indian Medical Gazette 2012:353-64.

[16] Mohapatra M, Satyanarayana S. Evaluation of clinico: pathologic findings of breast carcinoma in a general hospital in southern India. Indian Journal of Cancer 2013;50(4):297-301.

[17] Darbre PD. Recorded quadrant incidence of female breast cancer in great britain suggests a disproportionate increase in the upper outer quadrant of the breast. Anticancer Res 2005;25(3c):2543-50.

[18] Sangeeta K, Voralla M, Kanchanmala GG, et al. Histopathological spectrum of breast lesions with reference to uncommon cases. J Obstet Gynecol India 2009;59(5):444-52.

[19] Olu-Eddo AN, Ugiagbe EE. Benign breast lesions in an African population: a 25-year histopathological review of 1864 cases. Niger Med J 2011;52(4):211-6.

[20] Rahman MZ, Sikder AM, Nabi SR. Diagnosis of breast lump by fine needle aspiration cytology and mammography. Mymensingh Med J 2011;20(4): 658-64.

[21] Yu YH, Wei W, Liu JL. Diagnostic value of fine-needle aspiration biopsy for breast mass: a systematic review and meta-analysis. BMC Cancer 2012;12:41.

[22] Jarwani PB, Patel DC, Patel SM, et al. Fine needle aspiration cytology in a palpable breast lump. GCSMC J Med Sci 2013;2(2):12-6.

[23] Gurung G, Ghimire RK, Lohani B. Mammographic evaluation of palpable breast masses with pathological correlation: a tertiary care centre study in Nepal. Journal of Institute of Medicine 2010;32(2):21-5.

[24] Houssami N, Ciatto S, Irwig L, et al. The comparative sensitivity of mammography and ultrasound in women with breast symptoms: an age-specific analysis. Breast 2002;11(2):125-30.

[25] Ahmadinejad N, Movahedinia S, Movahedinia S, et al. Association of mammographic density with pathologic findings. Iran Red Crescent Med J 2013;15(12):e16698.

[26] Saarenmaa I, Salminen T, Geiger U, et al. Validity of radiological examinations of patients with breast cancer in different age groups in a population based study. Breast 2001;10(1):78-81. 